Анатоль Брусевіч

Гродна

\title{
Экзістэнцыйнае падарожжа \\ Эдзіка Мазько
}

Характэрнай рысай, якая сёння вызначае рух цывілізацыі, з'яўляецца спроба разбурэння ўсіх існуючых межаў. Зразумела, ёсць бар'еры, вартыя пераадолення дзеля ўзаемаўзбагачальных стасункай. Але ёсць межы (маральна-этычныя, мастацка-эстэтычныя і некаторыя іншыя), пераход якіх правакуе духойную дэградацыю. Гэта вельмі бачна на прыкладзе сучаснай літаратуры, асабліва заходнееўрапейскай. Што да беларускай вербальнай прасторы, то ӱ ёй, як і ў Заходняй Еўропе, найбольш распаўсюджанымі метадамі руйнавання выступаюць дэкананізацыя класікі, вульгарызацыя мовы, эстэтызацыя, а нават культывацыя пошласці, апеляцыя не да пачуццяў, а да інстынктаў. Аўтары, якія не карыстаюцца падобным інструментарыем, рызыкуюць апынуцца па-за літаратурным працэсам, выпаўшы з поля зроку выдаўцоў і літаратурных крытыкаў.

Паэт Эдзік Мазько (1970-2011) з той кагорты сучасных беларускіх пісьменнікаў, чыя творчасць адкрыла прынцыпова новыя перспектывы для айчыннай літаратуры, але па прычынах, акрэсленых вышэй, не сталася аб'ектам пільнай увагі з боку рэцыпіентаў слова.

Дэбютаваў Э. Мазько ў канцы 80-х на старонках газеты "Гродзенскі Універсітэт" 1. У тыя часы гэта была прывабная пляцойка не толькі для мясцовых студэнтаў-літаратарай, але і для маладых пісьменнікай

1 Гл.: Е. Мазько, Tym (дыпиіх), "Гродзенскі Універсітэт" 1989, № 25 ад 20 снежня, c. 4 . 
3 іншых рэгіёнаў, у тым ліку і са сталіцы: у "Коле", літаратурным дадатку да "Гродзенскага Універсітэту", друкавалі свае творы Алесь Аркуш, Вітаўт Чаропка, Зміцер Санюк, Сяргей Мінскевіч, Вольга Акуліч i іншыя аўтары. Менавіта тады распачалося і згаданае пераадоленне межаўㄹ. Праўда, тагачасныя маладыя творцы выдатна ўсведамлялі, што існуе своеасаблівы "рубікон", які нельга пераходзіць, бо за ім няма мастацтва. Інакш кажучы, літаратурнае пакаленне, да якога належыць Э. Мазько, разумела, альбо прынамсі адчувала, што ёсць нацыянальны культурны канон, па-за якім літаратура мярцвее, траціць прывабнасць як для айчыннага чытача, так і для чытача звонку. На жаль, многія прадстаўнікі гэтага пакалення вельмі хутка трапілі у цень крыху маладзейшых калегаў, якія не прызнавалі ніякіх межаў.

Зрэшты, зусім незаўважаным Э. Мазько не назавеш. Хаця б з той прычыны, што яго згадвае $\ddot{\mathrm{y}}$ сваёй манаграфіi "Пісьменства $\ddot{\mathrm{y}}$ халодным клімаце: беларуская літаратура ад 70-х гг. ХХ ст. да нашых дзён" 3 англійскі літаратуразнавец Арнольд Макмілін. Зразумела, даследчык не ставіў перад сабой задачу грунтойна разгледзець творчасць Э. Мазько. Таму меркаванне аб постаці яшчэ аднаго менш значнага паэта, імя якога звязанае з Гарадзеншчынай4, А. Макмілін дазволій сабе сфармуляваць, маючы да дыспазыцы фактычна дзве крыніцы: літаратурна-мастацкі часопіс "Правінцыя" 5 і анталогію гарадзенскай паэзіі “Лябірынты прывіднага замку" ${ }^{6}$. Што праўда, спасылаўся прафесар і на анталогію беларускай паэзіi XX стагоддзя "Краса і сіла" 7, аднак вершы Э. Мазько, якія там знайшліся, былі перадрукаваныя з "Правінцы”". Але і гэтага хапіла, каб зрабіць слушную выснову: вершы Э. Мазько разнастайныя паводле тэматыкі $і$ формы, y іх няма нічога блазенскага. Ён чуйнь,, далікатны паэт, які, бясспрэчна, разумее сваё месца ў дойгай $і$ пачэснай традыџыі Беларус$\kappa a z a ~ С л о в a^{8}$. Да гэтых слоў А. Макміліна можна было б дадаць, што месца Э. Мазько недзе паміж Алесем Разанавым і Надзеяй Артымовіч

2 Гл.: Ю. Пацюпа, Постмадэрнізм, кальлска мая, "Arche" 2004, № 3, с. 249-278.

3 Гл.: А. Макмілін, Пісьменства ў халодным клімаче: беларуская літаратура ад 70-х ге. ХХ cm. да нашьих дзён, Беласток 2011, с. 637-641.

4 Тамсама, c. 637.

5 Гл.: "Правінцыя" 2000, № 1-2, с. 84-88.

6 Гл.: Лябірынты прывіднага замку: гарадз. клюб паэтаў: [анталёгія] / аўт. праекту, склад. і рэд. Ю. Гумянюк, Беласток 2000, с. 70-85.

7 Гл.: Краса і сіла: Анталогія бел. паэзіi XX cm. / склад. М. Скобла; навук. рэд. А. Пашкевіч, Мінск 2003, с. 822-823.

8 А. Макмілін, Пісьменства ў халодным клімаце, с. 641. 
(асабліва блізкія для гарадзенскага літаратара паэтыка і мастацкі светапогляд пісьменніцы з Падляшша; да таго ж Э. Мазько і Н. Артымовіч звязвалі сяброўскія стасункі, але гэта тэма для іншага артыкула).

Акрамя таго маем меркаванне яшчэ аднаго прафесіянала - гісторыка літаратуры Алы Петрушкевіч. У некаторых сваіх публікацыях, прысвечаных сучаснай гарадзенскай паэзіі, даследчыца надзяляе постаць Э. Мазько даволі станоўчымі характарыстыкамі. Варта тут адзначыць артыкулы "Пра гарадзенскі клуб паэтаў, або Лабірынты прывіднага замка"9 і "Каханне і смерць Едруся Мазько" 10. Апошні уяяуляе сабой цікавую інтэрпрэтацыю адзінай, пасмяротнай кнігі паэта "Займеньнікі” (Варшава 2012). Праўда, любая інтэрпрэтацыя гэта погляд звонку. А што там "унутры" паэзіі Э. Мазько, А. Петрушкевіч часцей за ўсё мяркуе паводле "знешніх" назіранняў. Зрэшты, у гэтым няма нічога дзіўнага, бо нават калі сам аўтар ласкава адкрывае даследчыку таямніцы "нутранога жыцця", варта помніць пра схільнасць пісьменнікаў да міфалагізацыі свайго творчага шляху, да пэўнай містыфікацыі, што, зразумела, толькі аддаляе ад ісціны.

Ісціна, якую нясе чытачу Э. Мазько не ляжыць на паверхні. Як слушна заўважае Ю. Пацюпа, гэты паэт заўсёды вылучаўся загадкаваю эзатэрычнасию11. Сапраўды, спосаб мастацкага светасузірання Э. Мазько вельмі спецыфічны. Гэта шлях ад сябе да таямніц сусвету і наадварот, экзістэнцыйнае падарожжа да ўнутраных адгалоскаў знешняй рэчаіснасці. Паэтыка ягоных твораў - форма, структура, тэхніка выканання верша, улюбёныя прыёмы, - усё гэта таксама адпавядае той хаатычнай накіраванасці, якую творца абірае ӱ якасці мастацка-эстэтычнага арыенціру. У залежнасці ад "месца дыслакацыі" паэта пад час гэтай своеасаблівай вандроўкі, мяняецца нават ягонае імя: Едрусь, Эдзік, Эдуард. Так, да 1998 года, а дакладней да публікацыі у часопісе "Калосьсе" нізкі вершаў "Каты і сабакі" ${ }^{12}$, паэт падпісваўся Едрусем Мазько. Апошнюю прыжыццёвую публікацыю аздабляе імя Эдуард ${ }^{13}$. Дарэчы, нельга ні у якім разе разбіваць творчасць паэта на пэўныя перыяды паводле таго, як былі падпісаныя яго вершы, хоць та-

9 Гл.: А. Петрушкевіч, Пра гарадзенскі клуб паэтаў, або Лабірынты прывіднага замка, "Маладосць" 2011, № 6, с. 95-97.

10 Гл.: А. Петрушкевіч, Каханне і смериь Едруся Мазько, “Дзеяслоў" 2013, № 5, c. $304-312$.

11 Ю. Пацюпа, Постмадэрнізм, кальлкка мая, с. 253.

12 Гл.: Э. Мазько, Kambl i сабакі, "Калосьсе" 1998, № 6, с. 65-67.

13 Гл.: Poccbı: Зборнік вершаў, Гродна 2010, с. 34-37. 
кая перыядызацыя яўна напрошваецца. Змена імёнаў сведчыць аб вышэй згаданым руху i, як гэта ні парадаксальна, аб цэласнасці творчай паставы. Падобны "парадокс" сустракаецца ў хрысціянскім уяўленні Бога - адзінага $\breve{y}$ трох асобах.

Максімальна наблізіцца да свету паэзіі Э. Мазько дазваляюць згаданыя раней "Займеньнікі", куды ўвайшлі творы з самых розных "перыядаў", аднак цэласнасць кнігі здзіўляе сваёй бездакорнасцю. Не пабаюся гучнай характарыстыкі, але "Займеньнікі" Э. Мазько ўяўляюць сабой сапраўды ідэальную кнігу, прадуманую да найдрабнейшых дэталяй. Тут няма ніводнага выпадковага верша, вобраза, слова. Пры гэтым кожны твор мае дакладна акрэсленае месца, як быццам бы аўтар расстаўляў фігуры на шахматнай дошцы, альбо збіраў з вершаў-пазлаў адмысловы ўзор. Зрэшты, так яно і ёсць: са старанна вывераных, адшліфаваных твораў (прыкладна трэць з іх у нязменным выглядзе перавандравала у “Займеньнікі" з розных часопісаў, анталогій ды калектыўных зборнікай) Э. Мазько будаваў ні што іншае, як мадэль свайго ўнутранага свету. Але паколькі ўнутраны свет чалавека, а тым болей паэта, мае зменлівы характар, то і пабудова яго мадэлі - гэта пастаянны працэс. Як бачым, ёсць пэўная логіка ў тым, што кніга пабачыла свайго чытача толькі пасля смерці аўтара. Адразу адзначым: кніга "Займеньнікі" ні ў якім разе не з'яўляецца незавершанай. Смерць не перапыніла над ёй працу, але паставіла апошнюю кропку, стаўшы ў нейкім сэнсе сааўтарам.

Яшчэ адзін цікавы момант, на які варта звярнуць увагу - гэта суадносіны назвы кнігі і назваў яе раздзелай. 3 аднаго боку, няма тут нібыта нічога дзіўнага: на вокладцы чытаем "Займеньнікі", а ўнутры бачым раздзелы “Я", “Ён”, “Яна", “Яны”. Але ж тады атрымліваецца, што і назвы ніякай няма. Бо нават калі не глядзець на вокладку і адразу пачаць гартаць старонкі, будзе бачна: перад намі займеннікі - "Я", "Ён", "Яна", "Яны". Гэта як кнігу назваць "Кнігай". Зрэшты, пад такой назвай маем ці не найважнейшую кнігу у гісторыі нашай цывілізацы, кнігу, якая таксама задумвалася як мадэль, але не свету асобнага чалавека, а духойнага свету ўсяго чалавецтва. Гаворка, вядома, ідзе пра Біблію. Дарэчы, у гісторыі літаратуры (асабліва у польскай) не аднойчы сустракаем падобныя выпадкі, калі аўтары адмаўляюцца ад традыцыйнай, функцыянальнай назвы, якая прыцягвала б чытацкую ўвагу і адкрывала прынамсі асобныя фрагмены мастацка-эстэтычнай сістэмы выдання. Так, напрыклад, першы двухтомнік паэзіі Адама Міцкевіча так і называўся: "Паэзія". Пад такой самай назвай павыходзілі зборнікі ў Юліюша Славацкага, Антонія Лянгэ, Казімежа 
Пшэрвы-Тэтмаера, Яна Каспровіча, славенскага паэта Францэ Прэшэрна і шэрагу іншых творцаў. Падобным прыёмам скарыстаўся аднойчы Анатоль Сыс, выдаўшы кнігу "Сыс" (Мінск 2002). Такую цікавую паставу некаторых аўтараў, сярод якіх і Э. Мазько, можна патлумачыць іх усведамленнем нетрываласці сувязі паміж мовай і мысленнем. Дзіўна, але чым канкрэтней, здаецца, назва, тым менш яна ў рэальнасці адпавядае ідэі, якую мусіць адлюстроўваць, становячыся у адносінах да апошняй нечым фальшывым, а часам нават варожым. У вершы "Дзень шосты" Э. Мазько піша менавіта пра такія стасункі паміж ідэяй і словам:

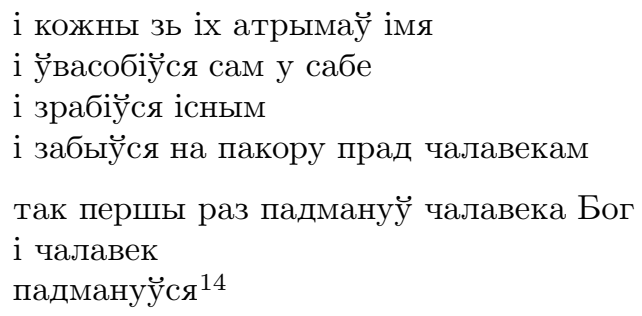

Перш чым паглыбіцца $\ddot{y}$ “Займеньнікі”, ва ўсе чатыры раздзелы, варта нагадаць, што дадзеную кнігу стварыў паэт-сюррэаліст. Гэта значыць, што у “Займеньніках" сфера падсвядомага значна пераважае над сферай разумовай. Таму многія вобразы і матывы, якія на першы погляд могуць падацца блізкімі, знаёмымі, зразумелымі, з'яўляюцца на самой справе толькі фантомамі, прывідамі выпадковых, спантаных асацыяцый аўтара. Па вялікаму рахунку, паэзія сюррэалізму уияўляе сабой "аўтаматычнае пісьмо", якое імкнецца вызваліцца з-пад кантролю розуму. Таму вельмі часта ў вершах сюррэалістай адсутнічаюць знакі прыпынку, асабліва коскі і кропкі. Гэта дазваляе пазбягаць узнікнення у тэксце ўсякага роду разумова-лагічных сувязей. Бо, на думку сюррэалістаў, такія сувязі яшчэ больш дэфармуюць, скажаюць светаадчуванне, у выніку чаго ўзнікае фальшывая рэальнасць, мутацыя рэчаіснасці:

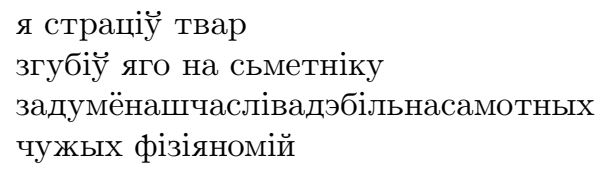

14 Э. Мазько, Займеньнікі. Вершы, Варшава 2012, с. 47. Далей пры спасылцы на гэта выданне ў дужках падаецца старонка. 


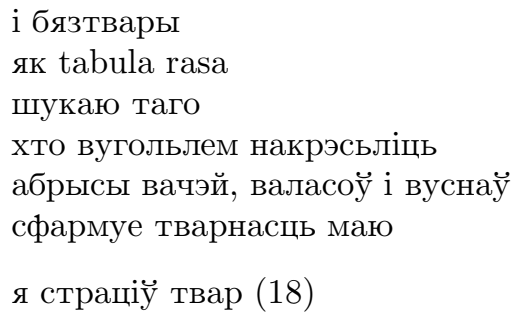

У дадзеным вершы, які, дарэчы, так і называецца - "Мутацыя", паказваецца шлях ідэі (шлях паэзіі ад аўтара да чытача), яе матэрыялізацыя у слове і страта праз гэта сваёй першапачатковай сутнасці. Матыў паўстання фальшывай рэальнасці сустракаем не ў адным вершы Э. Мазько. Трагічнай атмасферай падмены рэальнага ўяўным поўняцца і іншыя творы аўтара “Займеньнікаў”. Асабліва вылучаецца верш “Фальшывая адысея". Тут, акрамя згаданага матыву, прачытваецца яшчэ адзін сюррэалістычны матыў - аўтар сцвярджае змрочную залежнасць чалавека ад кону, лёсу, немагчымасць вызваліцца ад павуціння стэрэатыпаў, якімі кіруецца свет:

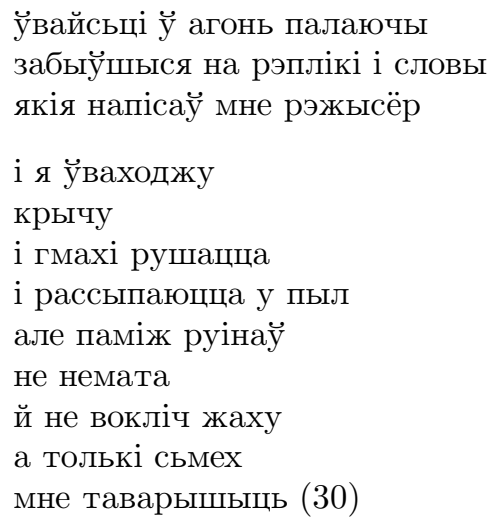

Увогуле творчасць Э. Мазько вылучаецца тэматычна-ідэйнай шматвектарнасцю: паэта цікавяць ці не ўсе сферы, у якіх праяўляе сябе чалавек. Не апошнюю ролю тут адыграла, відаць, пазалітаратурнае жыццё аўтара "Займеньнікай”, у якім Э. Мазько прафесійна займаўся гісторыяй, сацыялогіяй, культуралогіяй і культурнай антрапалогіяй.

Такім чынам, у цэнтры ўвагі Э. Мазько - чалавек, яго імкненне да волі, да творчасці, да жыцця, да Бога. Паэта цікавіць чалавек, які кахае, верыць, марыць, змагаецца, ненавідзіць, здраджвае, нараджаецца, жыве, памірае. Паэта цікавіць кожны рух унутранага і знешняга 
шляху чалавека, шляху ад сябе і да сябе. I гэты шлях, гэтую няпростую дарогу чалавечай, а перадусім уласнай экзістэнцыі, Э. Мазько спрабуе зафіксаваць, выкарыстойваючы інструментарый куды больш складаны, чым мае на ўзбраенні навука - праз мову паэзіі.

На мапе свайго сюррэалістычнага падарожжа аўтар "Займеньнікаў" абазначыў чатыры пункты, праз якія лёг шлях - "Я", "Ён", "Яна", "Яны". Нельга сказаць, што раздзел "Я" - нейкі цэнтр, альбо пункт адліку, як можа падацца на першы погляд. Гэтаксама як раздзел "Яны" нельга лічыць апошнім этапам, завяршэннем экзістэнцыйнай вандроўкі паэта. Яшчэ раз падкрэслю: "Я", "Ён", "Яна", “Яны" - усяго толькі пункты, праз якія пралягла дарога пазнання і самапазнання, своеасаблівыя кіламетровыя слупы, што абазначаюць адлегласць.

У раздзел “Я" патрапілі вершы, найбольш складаныя для інтэрпрэтацыі. Парадокс, аднак, у тым, што ніякага іншага дзеяння, апроч інтэрпрэтацыі, да іх не прыменіш - усе гэтыя творы абсалютна герметычныя. Раздзел "Я" - гэта своеасаблівы дзённік паэта, у якім з дапамогай мастацка-выяўленчых сродкаў зашыфраваныя асабістыя сакрэты і таямніцы. А знешне ўсё выглядае як добрая, густойная, філасофская лірыка. Каб не быць галаслоўным, зробім невялікую "разгерметызацыю" двух вершаў з прысвячэннем П. Л.

Першы верш - "Туга па агню". Для нагляднасці працытуем твор:

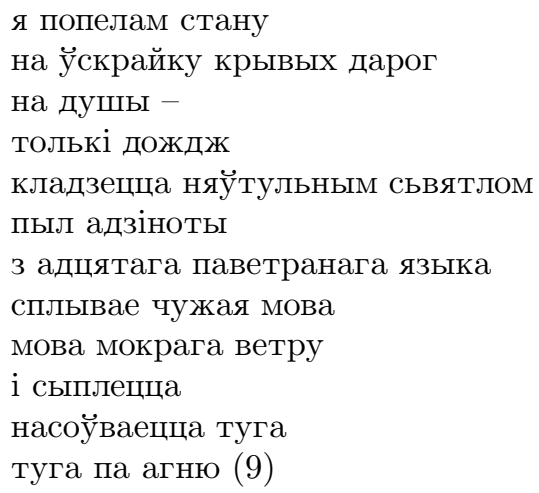

Пра што верш? Пра ўнутраную катастрофу? Пра страту духойных арыенціраў? Пра марнасць існавання? Пра адчужанасць і самаадчужанасць паэта? Пра неўзаемнае каханне? Проста пра каханне? Адказаў можа быць мноства - столькі, колькі чытачоў, а нават значна больш. Напрыклад, А. Петрушкевіч, аналізуючы твор, піша наступнае: Герой, які ведае, што такое холад, асабліва прагне ияпла. Ён здольнь знішчыць, спапялічь сябе, каб толькі далячещь да агню (...) дзе агонь - 
каханне $e^{15}$. I, канешне, даследчыца мае рацыю, бо гэта яе прачытанне... самой сябе. Так менавіта задумваўся першы раздзел "Займеньнікаў": схаваць аўтарскае "я" за люстранымі сценамі агульначалавечых праблем і каштойнасцей, каб кожны чытач мог бачыць толькі ўласны адбітак, сваё "я". Дык што на самой справе схавана ӱнутры верша? Ключ да разгадкі - ініцыялы П. Л, за якімі хаваецца... вышэй згаданы А. Сыс, аўтар кнігі "Пан Лес" (Мінск 1989). Дык вось аднойчы у Э. Мазько разгарэўся з А. Сысом пэўны канфлікт, пасля чаго быў напісаны верш "Туга па агню", які зафіксаваў гісторыю гэтага непрыемнага здарэння. Так што агонь у дадзеным вершы не ўвасабляе каханне. Гэта хутчэй агонь пякельны, агонь злосці, крыўды, нават нянавісці. 3 часам, праўда, Э. Мазько дараваў А. Сысу, які быў вінаваты ў тым канфлікце, што зафіксавана $\breve{y}$ чарговым вершы з вядомымі ӱжо ініцыяламі П. Л.:

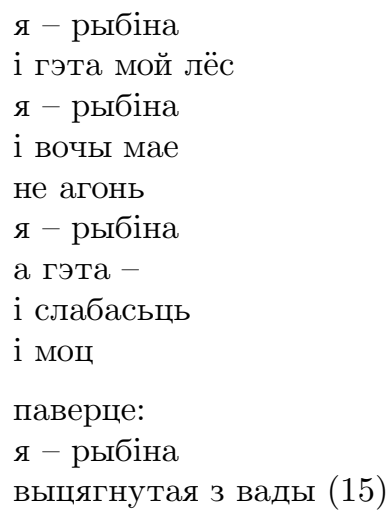

Безумоўна, вобраз рыбіны, які ўзікае ў творы, можна трактаваць па-рознаму, асабліва ўлічваючы той факт, што Э. Мазько быў культуролагам і мог скарыстацца 3 любога вядомага ў гісторы сусветнай культуры сімвалічнага значэння рыбы. Але тут прысутнічае выключна хрысціянская сімволіка, паводле якой рыба можа сімвалізаваць Хрыста, яго паслядоўнікаў, Святую Троіцу (тры пераплеценыя рыбы) і інш. Нагадаем таксама, што з рыбай звязаны многія евангельскія гісторыі, якія маюць вялікае значэнне для зразумення асноў хрысціянскага вучэння. Так, прыкладам міласэрнасці служыць гісторыя пра тое, як Хрыстос пяццю хлябамі і дзвюмя рыбінамі накарміў тысячы людзей (Мацф. 14: 15-21). У вершы Э. Мазько рыбіна таксама

15 А. Петрушкевіч, Каханне і смериь Едруся Мазько, с. 306. 
сімвалізуе хрысціянскую міласэрнасць. Называючы сябе рыбінай, паэт абвяшчае, што даруе свайму крыўдзіцелю. Праўда, у заключных радках бачым, што такая пастава даецца аўтару верша вельмі нялёгка, гэтак, як нялёгка рыбіне, выцягнутай з вады.

Акрамя выкарыстання хрысціянскай сімволікі, якая з'яўляецца ключом да прачытання многіх вершаў Э. Мазько, паэт, маючы досвед культуролага, умела карыстаецца вобразамі, запазычанымі з антычнай спадчыны. Яны таксама вельмі арганічна ўплятаюцца аўтарам “Займеньнікаў” у сістэму беларускага культурнага коду і эмацыйна уззмацняюць усе прысутныя ў кнізе мастацка-эстэтычныя спецэфекты. Цікавы ў гэтым сэнсе верш "Аід". Перад чытачом паўстае плынь свядомасці лірычнага героя, які апынуўся $\ddot{y}$ адным $з$ гарадзенскіх пастарункай, дзе

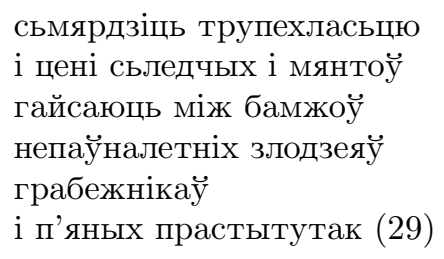

На першы погляд працытаваныя радкі выглядаюць як даволі непрыглядная, цалкам рэалістычная замалёўка. I толькі параўнанне $\ddot{y}$ другой частцы верша будзёнай рэчаіснасці 3 Аідам (царствам мёртвых у старажытнагрэцкай міфалогіi), а лірычнага героя з Праметэем змяшчае ўсе рэалістычныя акцэнты. У выніку паўстае цалкам іншая, сюррэалістычная карціна.

Экзістэнцыйнае падарожжа паэта да спробы спасціжэння агульначалавечых законаў, ад якіх усё часцей адмаўляецца сучасны свет, ляжыць праз лабірынты самапазнання. А у іх вельмі лёгка заблукаць, страціць сэнс пошукаў ісціны:

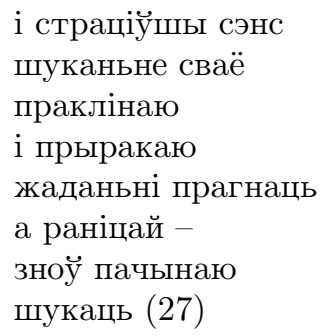

Гэта радкі з верша "Дао". Назва твора, як і ӱ выпадку з вершам "Аід", дае знаць, што пошукі ісціны не абмяжоўваюцца толь- 
кі шляхамі ўласнага "Я". Не будзем падрабязна спыняцца на катэгорыі "дао", якая з'яўляецца самай складанай у кітайскай класічнай філасофіi. Звернем увагу на тое, што ўвёўшы гэты канцэпт у сістэму сваёй мастацкай прасторы, Э. Мазько як мінімум сцвярджае неацэнную каштойнасць беларускай ідэі, а ў адначассі ўсю складанасць, парадаксальнасць і хаатычнасць беларускага шляху. Дарэчы, матыў шляху яшчэ з нашаніўскіх часой - адзін з вядучых, цэнтральных матываў айчыннай літаратуры. Ён фактычна сфармаваў аблічча нашага вербальнага мастацтва. Гэты самы класічны беларускі матыў, як бачым, з'яўляецца скразным і ў паэзіі Э. Мазько. Ягоны лірычны герой знаходзіцца у тым самым адвечным пошуку, што і героі Янкі Купалы і Якуба Коласа, Максіма Багдановіча і Вацлава Ластойскага. Праўда, да Э. Мазько нярэдка прыходзіць думка, што гэты шлях - сусьветная немата (6), што няма і не было ніколі сэнсу // у руху, у гэтай спрадвечнае таўкатні (25). Аднак помнім: для паэзіі сюррэалізму сэнс, рацыянальнасць, логіка - атрыбуты падману. Таму яе лірычны герой, не зважаючы на ўнутраныя і знешнія пасткі і пусткі, смела заяўляе:

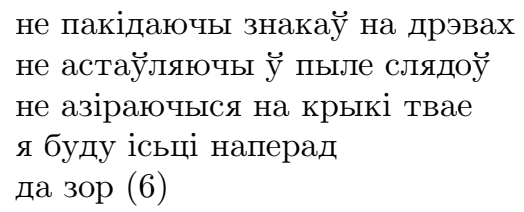

Нельга не заўважыць тут пэўнае перагуканне з вядомым Багдановічаўскім вершам "Я хацеў бы спаткацца з Вамі на вуліцы". Увогуле, паэзія М. Багдановіча аказала вялікі ўплыў на фармаванне творчай свядомасці аўтара "Займеньнікаў”. Перадусім урбаністычная лірыка класіка, роўнай якой няма ні ў сучаснікаў, ні ӱ большасці спадкаемцай песняра чыстай красы. Сярод сучасных беларускіх паэтаў, Э. Мазько, магчыма, найбольш выразны і цікавы майстар урбаністычнага пейзажу, здольны у у адно цэлае аб'яднаць гісторыю і сучаснасць гораду, пры гэтым захаваць усе яго колеры, мелодыі і нават пахі. У кнізе “Займеньнікі" ёсць вершы, прысвечаныя Вільні і Мінску, Любліну і Бельску. Ёсць у паэта і вершы, у якіх прачытваеццца абагулены вобраз гораду (найбольш багатую палітру чыста гарадскіх матываў маем у раздзеле "Яны"). Аднак у кожным вершы Э. Мазько (і не толькі у тых творах, што аздобілі кнігу) прысутнічае нешта, што можна было б умоўна назваць "гарадзенскім духам". Які б верш мы ні ӱзялі з яго пазірае Гародня. Зрэшты, дзіўнага тут мала: з Гародняй звязана усё духойнае жыццё Э. Мазько - з чэрвеня 1987 года, калі ўчорашні 
школьнік прыехаў у гэты горад працягваць адукацыю і да чэрвеня 2011 года, калі душа паэта адляцела ў гарадзенскія нябёсы. У Гародні, нагадаем, адбыўся творчы дэбют Э. Мазько, тут ён спаткаў сяброй-аднадумцаў і проста братоў па пяру, з якімі ўтварыў у 1989 годзе даволі ӱнікальнае для тагачаснай культурнай сітуацыі паэтычнае аб'яднанне пад назвай верш-гурт “Дыяген” 16. У Гародні Э. Мазько спраўдзіўся і як прафесійны вучоны, пра што было згадана вышэй. Урэшце, у гэтым горадзе паэт спаткай сваё каханне і стварыў сям'ю. Што да “Займеньнікай", то асабліва прасякнуты "гарадзенскасцю" другі раздзел гэтай кнігі - "Ён". Паколькі Гародня падарыла Э. Мазько фактычна ЎС̈̈,

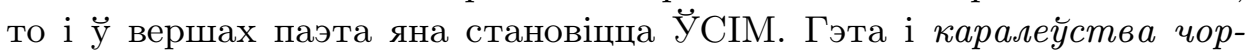
нага спакою // і музыка небыиьия // зачараваная ў кола ўцёкаў (34), і свой Дом // утульны й гасьиіннь // да прыблуднага сына (44), па-за якім нават кроплі дажджу па-іншаму грукаючь ў шыбы (46). Зразумела, жыццё мае і свае непрывабныя бакі: яму спадарожнічаюць і боль, i трывога, і расчараванне. Таму Гародня ў паэзіi Э. Мазько паўстае не толькі як маці, гатовая заўсёды прыняць свайго пакамечанага cblна (35), альбо добрая бабуля-чараўніца, якая звычайнага, будзёнага і нецікавага мінака робіць вялікім паэтам // нязнанылм і разам славутылм // геніем ў кожныл імгненьні самоты (40). Гародня - гэта яшчэ і валадарства немать // i глухаты // i слепать (45), i буркаченьне тэлефону // з якога галась сяброй // радзей чуваць // за лямант незнаёмых (48). Так ці інакш, Гародня запаўняе сабой усю мастацкую прастору вершаў Э. Мазько, паступова ператвараючыся са звыклага вобраза ў шматзначны сімвал духойнага жыцця паэта. Такім чынам "Ён" у кнізе - не толькі горад, але і край, і свет, і Бог, i, нарэшце, сам аўтар. Менавіта таму ў дадзеным раздзеле былі змешчаны вершы, якія не маюць нічога агульнага 3 матывам гораду, напрыклад, верш "Дзень шосты", створаны паводле біблейскага сюжэту, альбо верш "Мур", які адлюстроўвае ўсю складанасць і парадаксальнасць спосабу чалавечага існавання ў гэтым свеце. Дарэчы, верш "Мур" цікавы не толькі ідэйна-эстэтычным напаўненнем, але і сваім месцам у кнізе. За "Мурам" пачынаюцца раздзелы “Яна" і “Яны", у якіх эстэтыка сюррэалізму паступова саступае месца эстэтыцы дэкадансу. Зразумела, правесці дакладную мяжу паміж гэтымі плынямі немагчыма, паколькі у нерэалістычнага мастацтва адна прарадзіма - эпоха рамантызму. Таму тэматыка, праблематыка, ідэалогія твораў сюррэалізму і дэка-

16 Гл.: Ю. Пацюпа, Постмадэрнізм, кальцкка мая, с. 253-255. 
дансу амаль ідэнтычныя. Што іх адрознівае, дык гэта тэмперамент: паэт-сюррэаліст - бунтар, ваяр, рэвалюцыянер, ён бачыць недасканаласць свету і прагне яго змяніць, стварыць новую рэальнасць (надрэальнасць); паэт-дэкадэнт бачыць свет тымі самымі вачыма, у тым самым святле, аднак у яго няма жадання нічога мяняць - ён не верыць у надрэальнасць. Зрэшты, дэкадэнт не верыць ні ўва што - ні ў каханне, ні у у сяброўства, ні у радзіму, ні у сябе. Адзіная рэальнасць, у якой ён не сумняецца - гэта смерць. Матывам смерці і яе спрадвечнымі атрыбутамі - адзінотай, тугой, трывогай, асуджанасцю і безвыходнасцю прасякнуты "Займеньнікі" па-за "Мурам". Сам жа "Мур", які раздзяляе сюррэалізм ад дэкадансу, узведзены такім чынам, што y ім арганічна спалучаюцца неўтаймаваная ваяўнічасць і трагічнае бяссілле, святло надзеі і змрок расчаравання, дынаміка і статыка:

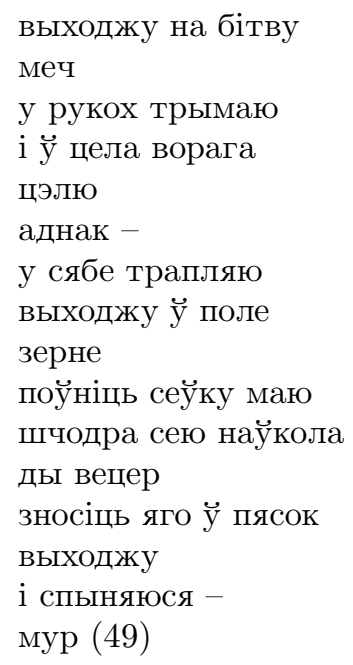

Э. Мазько не любіць рэзкіх кантрастаў. Таму і пераход да дэкадансу у яго плаўны. Нават назва самага дэкадэнцкага раздела кнігі (а гэта раздзел "Яна") перш за ўсё асацыюецца з жанчынай, а значыць з каханнем, з пяшчотай, з надзеяй, у рэшце рэшт. Аўтар яшчэ і быццам падыгрывае гэтым асацыяцыям, ачоліӱшы раздзел трыма лірычнымі вершамі пра жанчыну (жонку-каханку-маці). Аднак, не забывайма, што маем справу з займеннікамі. У кнізе Э. Мазько яна - гэта... Паставім пакуль шматкроп'е, бо каб зразумець, што крыецца за займеннікам "Яна", трэба прайсці праз... смерць. Яна запаўняе сабой усе тыя пусткі экзістэнцыі паэта, якія па законам рацыянальнасці павінны былі б запоўніцца чым заўгодна, але толькі не ейнай ірацыянальнасцю. 
Што да першых трох вершаў у раздзеле "Яна", то гэтыя творы сімвалізуюць своеасаблівы шлях да пустэчы (пустэча у нашым выпадку тоесная гармоніi, бо ӱвасабляе стан абсалютнай нейтральнасці ў дачыненні да акаляючай рэчаіснасці). Вобраз жанчыны дапамагае аўтару максімальна развіць дадзеную ідэю, зрабіць яе даступнай на самых розных узройнях свядомасці, у тым ліку на асацыятыўным узройні. Так, у першым вершы, лірычны герой (сам аўтар), перапоўнены жыццём (жарсцю, каханнем, самотай), прагне вызваліцца ад усяго гэтага і вярнуцца да гармоніi. Скептык, дарэчы, можа запярэчыць, маўляў у першым вершы няма жаднай жарсці, таму і пра спусташэнне казаць не варта. Варта! Перад намі не проста верш, але акраверш. Адзінае, у кнігу выпадкова трапіў чарнавы яго варыянт. Аднак і ў ім, няхай не цалкам, але захаваліся зашыфраваныя словы кахання. Справядлівым будзе прывесці чыставік згаданага твора:

\section{Галi}

Кроплі зімовага дажджу

Адбіваюць мелодыю суму

Хутка ноч

Ападзе на Вільню

Ноч сьляпая як дождж

Ападзе на Вільню

Я стаю ля вакна

Я гляджу на усход

Сам-насам ля вакна

Углядаюся ў дождж

Моўчкі ноч

Упадзе на Вільню

Юркі дождж

Пазмываў усе знакі

Абабіў ліхтары і дрэвы

Толькі ноч

Ападзе на Вільню

Безсэнсоўна скасуе дзённы

Енк і плач ${ }^{17}$.

Другі верш, як і першы, утрымлівае ў сабе далікатны эратызм, але цяпер з дапамогай няўлоўнай эротыкі паказваецца стан героя адразу пасля вызвалення: пустэча акрыляе яго, робіць (прынамсі на нейкі час)

173 архіва Галіны Мазько. 
валадаром сувету. Трэці верш, "Старая", сцвярджае ідэю нетрываласці валадарства таго, хто прагне спусташэння. Бо над светам і жыццём можа валадарыць толькі той, хто напойнены жыццём і светам. Адсюль рацыянальны аптымізм і ірацыянальны песімізм дадзенага верша:

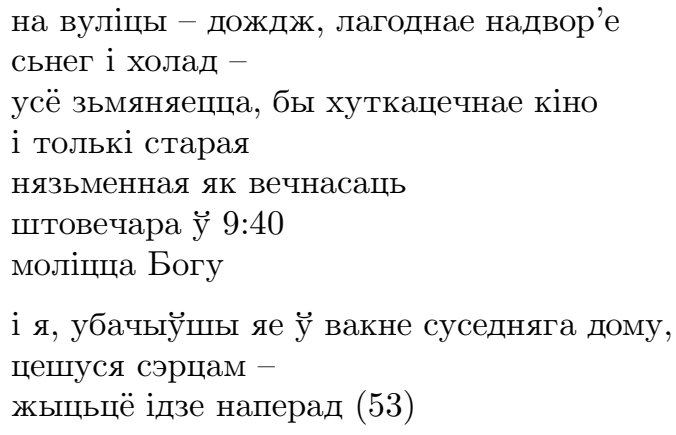

Нарэшце, чацвёрты верш перадае стан поўнай пустэчы, калі ўжо не важна, што чакае наперадзе і чым гэтая пустэча напойніцца - рацыянальнасцю жыцця, альбо ірацыянальнасцю смерці:

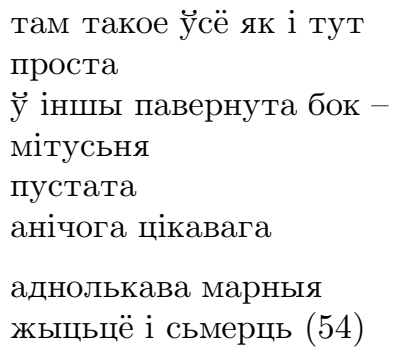

I толькі з пятага верша пачынаецца паэзія чыстага дэкадансу: пустэчу запойніла смерць. Але паколькі Э. Мазько не з'яўляецца аматарам рэзкіх кантрастаў, то спачатку перад чытачом паўстае не сама смерць, а толькі яе сляды. "Сьляды сьмерці" - трыпціх, які павольна, паступова аддаляе ад іманентнага і набліжае да трансцэндэнтнага. За "Сьледам трэцім" паўстае царства Плутона ${ }^{18}$, дзе вечны змрок // сваё пасеяў пустазельле // па берагох няўлойнае ракі (57). Далей ідзе верш "Жаданьні", які па-за кнігай "Займеньнікі" мог бы сысці за лёгкі лірычны верш пра каханне. Зрэшты, ён сапраўды пра каханне, толькі паэт прызнаецца ў сваіх палкіх пачуццях не жанчыне, а смерці.

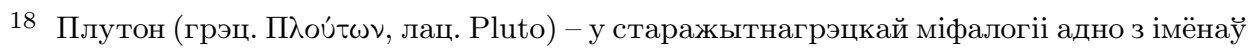
бога - валадара царства мёртвых. 
Дзіӱнага тут нічога няма: перад намі нерэалістычнае мастацтва, створанае паэтам-дэкадэнтам. I вось адбываецца першае спатканне лірычнага героя з аб'ектам жарсці (верш "Спроба ідэнтыфікацыі сьмерці"), але у у ірацыянальным свеце ўсё выглядае зусім не так, як дыктуе звыклая логіка. Таму

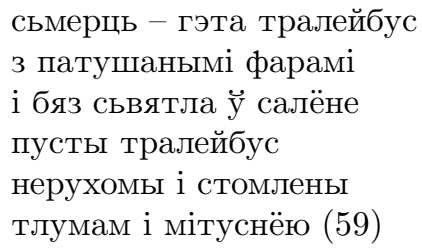

А далей паэт знаёміць чытача 3 усімі абліччамі, якія прымае смерць, прынамсі тымі, што сам аднойчы бачыў. Так, напрыклад, смерць амаль заўсёды мае аблічча безнадзейнасці, калі не чутно званоў // i съвет робічиа дробньм // як раструшчанае шкло (60). Сінонімам смерці становіцца кастрычніцкая ноч, што як злодзей у сад // залезла // i абрывае лісьче з ябльняй (61). Самае ж страшнае ўвасабленне смерці знаходзім у вершы “Дзень волі". Гэта верш пра смерць радзімы і смерць свабоды. Зрэшты, для мастака, чыю пустэчу аднойчы запойніла смерць, усе яе маскі аднолькава жахлівыя

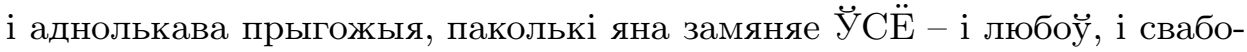
ду, і радзіму. Аднак мастак не забывае і пра тое, што некалі ён быў пустым, а перад тым перапоўненым, але не ірацыянальнасцю смерці, а рацыянальнасцю жыцця. А гэта азначае, што ёсць нешта больш магутнае і за жыццё, і за смерць, нешта, што рассычае ў сабе боль і пакуты, хавае пад покрывам вечнылм // пошукі шляху // бобіі й жахі // роспач (63), што соіць вечнай надзеяй // нязбыйнымі марамі // пэўнасьцю ў марнасьиі // сьмериі й жыцьия (63). Нельга адназначна сцвердзіць, што Э. Мазько тут мае на ўвазе Бога, як не можам і адхіліць дадзеную версію, улічваючы ўсю непрадказальнасць і парадаксальнасць творчай свядомасці паэта. Так ці інакш, гэтае НЕШТА ўвасоблена ў вобразе цемры, да якой лірычны герой моліцца у заключным вершы раздзела "Яна":

будзь блаславёнай ад сёньня й назаўшы цемра зь якой пачалося і скончыцца ўсё існае (63) 
Такім чынам, мы маем адказ на пастаўленае вышэй пытанне: пад займеннікам "Яна" хаваецца ЦЕМРА, якую можна суаднесці калі не з Богам, то 3 першаасновай быцця: $A$ зямля была нябачная $і$ пустая $i$ чемра над безданню, $i$ Дух Божьл лунаў над вадою (Быццё 1:2).

Дарэчы, апошні раздзел "Яны", выглядае якраз той безданню, над якой распрасцёрлася цемра першых трох раздзелаў кнігі. Гэта вершы, якія могуць існаваць без аўтара: па-першае, яны пазбаўленыя баласту патаемных сэнсаў, вядомых толькі творцу, альбо вузкаму колу блізкіх да яго людзей і нясуць у сабе пераважна філасофска-эстэтычны зарад; па-другое, яны адлюстройваюць пэўныя этапы жыцця паэта, вяртанне да якіх альбо немагчымае, альбо непажаданае. Калі б, напрыклад, Э. Мазько назваў кнігу не "Займеньнікі", а "Катэгорыі часу", то раздзел "Яны" мог бы атрымаць назву "Мінулы час", альбо нават "Плюсквамперфект". Цэнтральная ідэя раздзела, ідэя "невяртання", бачная з першага ӱжо верша пра мокры вугаль, які нічьлм ня пахне // можа толькі згарэльлм жытлом // $i$ сумам па страчаныл доме (65). Наступны верш, верш "На выгнаньні", паглыбляе гэтую ідэю, паказваючы, як лёгка размываюцца, губляюцца непарушныя, здаецца, сувязі, як тое, што ўчора было блізкім, сёння становіцца чужым і незразумелым. Чарговыя творы толькі ўзмацняюць трагічнае адчуванне нетрываласці гэтага свету. Многія вершы нагадваюць старыя фотаздымкі, на якіх жыве даўно страчаная рэальнасць. Такім чынам, галоўная праблема, якую аўтар "Займеньнікай” уцелясняе $\ddot{y}$ раздзеле "Яны", гэта праблема часу. Праўда, не толькі мінулага (хоць ён і пераважае), але часу ӱвогуле. Паколькі дадзены раздзел, як і папярэдні, вытрыманы ӱ духу эстэтыкі дэкадансу, то і час выступае тут як варожая, знішчальная сіла, супрацьстаяць якой няма сэнсу. На гэтай трагічнай ноце і скончваецца кніга паэзіі "Займеньнікі":

час працінае мае вершы
і няма іх ужо
толькі блядныя цені
дым цыгарэтны
разсычаны у паветры $(86)$

На падставе вышэй сказанага можна зрабіць наступныя высновы:

- Творчасць Э. Мазько ўяўляе сабой цікавы, аднак мала даследаваны феномен у сучасным беларускім вербальным мастацтве;

- Паэзія Э. Мазько абапіраецца на лепшыя традыцыі заходнееўрапейскага сюррэалізму і дэкадансу, а таксама на мастацка-эстэтыч- 
ныя пошукі айчыннага прыгожага пісьменства пачатку XX стагоддзя;

- Даволі поўна і паслядоўна светапогляд Э. Мазько адлюстраваны у невялікай па аб'ёме кнізе “Займеньнікі”, якая дае між тым магчымасць наблізіцца да адэкватнага ўспрымання ўсёй творчасці пісьменніка, раскінутай па самых розных беларускіх і замежных выданнях.

STRESZCZENIE

\section{PODRÓŻ EGZYSTENCJALNA EDZIKA MAŹKO}

W artykule zwrócono uwagę na szereg pierwiastków artystycznych w poezji jednego z niedocenionych współczesnych poetów białoruskich Edzika Maźko (1970-2011). Spuścizna literacka przedwcześnie zmarłego poety jest z pogranicza estetyki surrealizmu i dekadentyzmu.

Słowa kluczowe: poeta białoruski, surrealizm, dekadentyzm, zaimek osobowy, miłość, śmierć, miejski pejzaż.

\section{S U M M A R Y}

\section{EDICK MAZKO'S EXISTENTIAL PEREGRINATION}

In the article the attention is concentrated on the specific art of Edick Mazko's poems (1970-2011). He is one of the underestimated modern Belarusian poets whose heritage is located in the esthetic area of surrealism and decadence.

Key words: Belarusian poetry, surrealism, decadence, pronouns, love, death, urban landscape. 